\title{
INTERACTION OF HUMAN SPERM ACROSOMAL PROTEINASE WITH HUMAN SEMINAL PLASMA PROTEINASE INHIBITORS
}

\author{
L. J. D. ZANEVELD, G. F. B. SCHUMACHER, \\ H. FRITZ, E. FINK AND E. JAUMANN
}

Section of Reproductive Biology, Department of Obstetrics and Gynecology, The University of Chicago, Pritzker School of Medicine, 5841 South Maryland Avenue, Chicago, Illinois

60637, U.S.A., and The Institute for Clinical Chemistry and Clinical Biochemistry,

University of München, D 8 München E-2, Nussbaumstrasse 20, Germany

(Received 29th August 1972)

Summary. Human sperm acrosomal proteinase is immediately inhibited by the Fraction I (mol. wt. 12,700) and Fraction II (mol. wt. $5,400)$ proteinase inhibitors of human seminal plasma. The Fraction II inhibitor inhibits acrosomal proteinase much more effectively than the Fraction I inhibitor, having an association constant of $5.0 \times 10^{8} \mathrm{M}^{-1}$ and a dissociation constant of $2.0 \times 10^{-9} \mathrm{M}$. The results provide further evidence for the possible rôle of the Fraction II inhibitor in the reproductive process.

Evidence has been presented that in some species, seminal plasma proteinase inhibitor is added to spermatozoa and removed again while the spermatozoa reside in the female genital tract (Zaneveld, Srivastava \& Williams, 1969, 1970). It was further established that the presence of proteinase inhibitors on spermatozoa prevents fertilization (Stambaugh, Brackett \& Mastroianni, 1969; Zaneveld, Robertson \& Williams, 1970; Zaneveld, Robertson, Kessler \& Williams, 1971). This antifertility effect is probably obtained by inhibition of the sperm acrosomal proteinase (acrosin), an enzyme that appears essential for the penetration of the spermatozoon through the zona pellucida. Recently, the acrosomal proteinase of ejaculated human spermatozoa was partially purified and characterized (Zaneveld, Dragoje \& Schumacher, 1972). The enzyme is released from the spermatozoon in complex with an inhibitor. Two proteinase inhibitors (Fraction I, mol. wt. $=12,700$ and Fraction II, mol. wt. $=5400$ ) have been isolated from human seminal plasma (Fink, Jaumann, Fritz, Ingrisch \& Werle, 1971). The objective of the present study was to evaluate the kinetics and strength of interaction of the human seminal plasma proteinase inhibitors with human sperm acrosomal proteinase.

Acrosomal proteinase was obtained by detergent treatment of washed, ejaculated human spermatozoa. The enzyme was partially purified by Sephadex G-50 gel filtration using an acidic buffer to separate the enzyme from inhibitor (Zaneveld et al., 1972). The proteinase inhibitors were isolated from seminal plasma by CM-Sephadex C-25 adsorption, affinity chromatography and Sepha- 


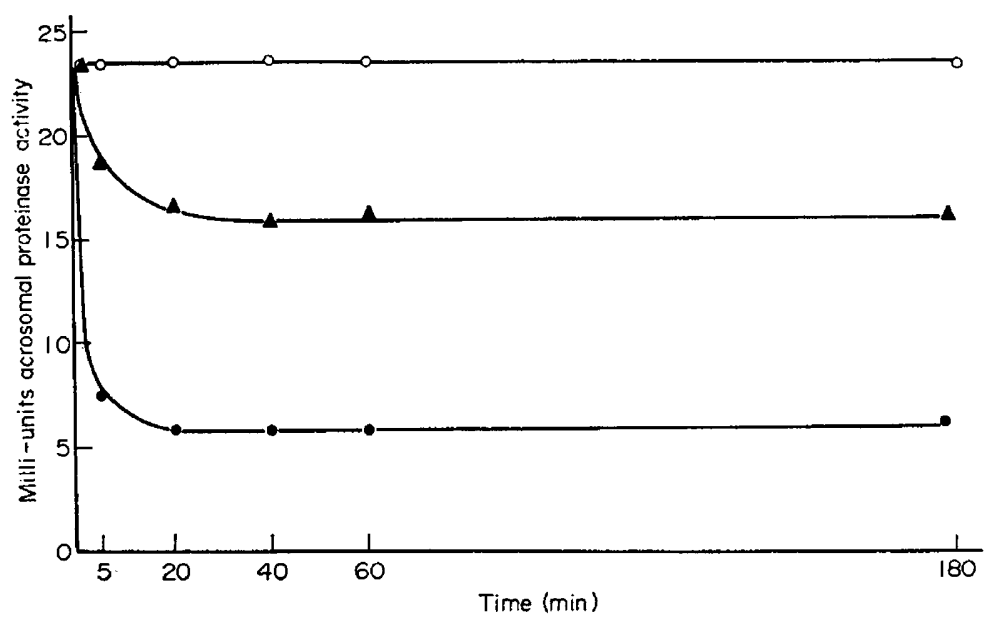

TExr-pIG. 1. Time relationship of the inhibition of human acrosomal proteinase by human seminal plasma proteinase inhibitors. $O$, Saline control; $\Lambda$, Fraction I; $\bullet$, Fraction II.

dex G-75 gel filtration (Fink et al., 1971). Enzyme activity was evaluated by addition of the test solution to $3.0 \mathrm{ml}$ benzoyl arginine ethyl ester (BAEE, Sigma Chemical Co., $0.2 \mathrm{mg} / \mathrm{ml}$ ) in $0.1 \mathrm{~m}$-borate buffer, $\mathrm{pH} 8.0$, containing $0.05 \mathrm{M}-\mathrm{CaCl}_{2}$ and measuring the change in absorbance at a wavelength of $253 \mathrm{~nm}$ for $5 \mathrm{~min}$ (Schwert \& Takenake, 1955). One milli-unit (mU) of activity was defined as that amount of enzyme that causes a rate of change of $0.001 \mu \mathrm{mol} \mathrm{BAEE} / \mathrm{min}$. Protein estimations were made by absorption readings at a wavelength of $280 \mathrm{~nm}$, assuming that $1 \mathrm{mg}$ of protein $/ \mathrm{ml}$ has an optical

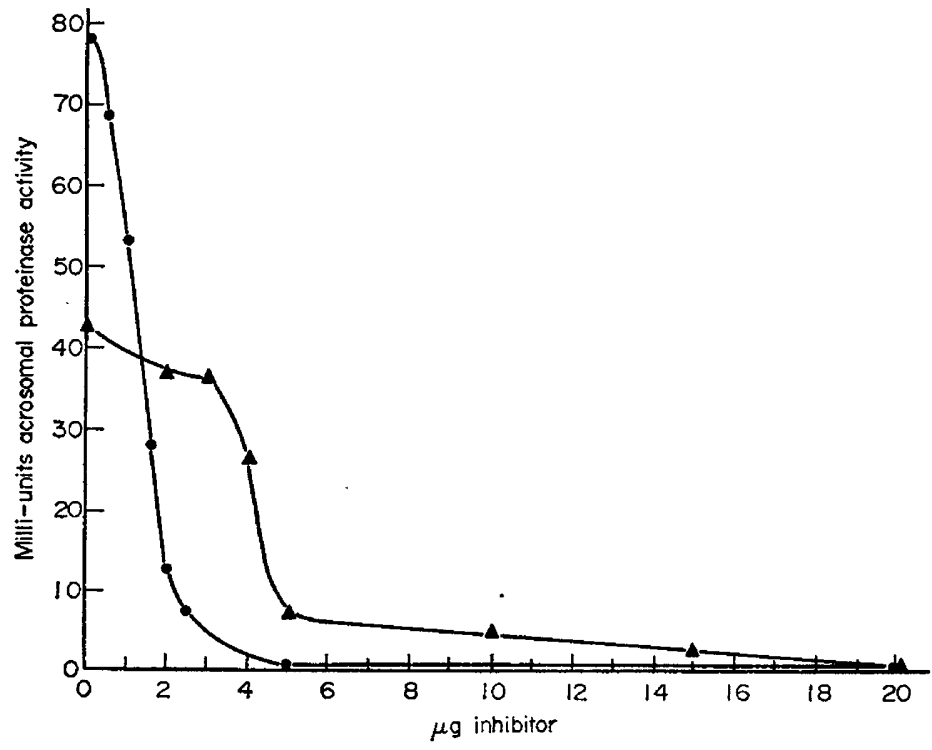

TExT-Frc. 2. Inhibition of human acrosomal proteinase by varying amounts of human seminal plasma proteinase inhibitors. $\Delta$, Fraction I; 0 , Fraction II. 
density of 1.0 using a $1-\mathrm{cm}$ light path. On this basis, the activity of the acrosomal proteinase preparation used was $2100 \mathrm{mU} / \mathrm{mg}$ protein. Inhibitor tests were performed by two different methods: (1) the acrosomal proteinase preparation $(0.6 \mathrm{ml}, 65 \mu \mathrm{g})$ in the substrate buffer was incubated with inhibitor $(3 \mu \mathrm{g}, 0.3 \mathrm{ml})$ in $0.15 \mathrm{M} \mathrm{NaCl}$ at room temperature. Aliquots $(0.15 \mathrm{ml})$ were tested for activity at various times (Text-fig. 1); (2) the acrosomal proteinase preparation $(0.15 \mathrm{ml}, 30 \mu \mathrm{g}$ in the case of the Fraction I inhibitor and $55 \mu \mathrm{g}$ in the case of the Fraction II inhibitor) was mixed with various amounts of inhibitor $(0.15 \mathrm{ml})$. After incubation at room temperature for $5 \mathrm{~min}, 0.2 \mathrm{ml}$ of the solution was tested for activity (Text-fig. 2). As control, the acrosomal proteinase preparations were incubated with $0 \cdot 15 \mathrm{M} \mathrm{NaCl}$ under the conditions described for each test.

The Fraction II inhibitor inhibits human acrosomal proteinase rapidly (Text-fig. 1) and in very small amounts (Text-fig. 2). From the linearity of the inhibition curve (Text-fig. 2), it can be concluded that $1 \mathrm{~mol}$ enzyme reacts with 1 mol inhibitor (Laskowski \& Sealock, 1971). Extrapolation of the linear part of the curve shows that $2 \cdot 2 \mu \mathrm{g}$ inhibitor should completely inhibit $78 \mathrm{mU}$ acrosomal proteinase. In practice, only $88 \%$ of the enzyme is inhibited. From this, the association constant of the reaction can be calculated as $5.0 \times 10^{8} \mathrm{M}^{-1}$ and the dissociation constant as $2.0 \times 10^{-9} \mathrm{M}$ (Green \& Work, 1953).

The Fraction I inhibitor is also an 'immediate' inhibitor but inhibits human acrosomal proteinase much less effectively than the Fraction II inhibitor (Text-fig. 1). This correlates with the relative effect of these inhibitors on bull (Suominen \& Niemi, 1972) and boar (Fritz, Forg-Brey, Fink, Schiessler, Jaumann \& Arnhold, 1972) acrosomal proteinase. Increasing amounts of Fraction I inhibitor initially do not diminish enzyme activity significantly until a certain point when a rapid decrease in enzyme activity occurs (Textfig. 2). Higher amounts of enzyme than that used in Text-fig. 2 necessitated proportionally larger amounts of Fraction I inhibitor to reach this point of rapid decrease. No explanation can be given at the present time, although the possibility exists that the Fraction I inhibitor interacts first with another enzyme that does not hydrolyse BAEE before the inhibitor reacts with the acrosomal proteinase. It has indeed been shown (Fink et al., 1971; Suominen \& Niemi, 1972) that the Fraction I inhibitor is an excellent inhibitor of chymotrypsin as well as trypsin, whereas the Fraction II inhibitor inhibits only trypsin. It is also possible, however, that the rather short incubation time of enzyme and inhibitor resulted in poor inhibition at low concentrations of inhibitor. The association constant of the Fraction I inhibitor cannot be calculated from the curve in Text-fig. 2, but appears to be much smaller than that of the Fraction II inhibitor.

The results show that the Fraction II inhibitor effectively inhibits the human acrosomal proteinase. Since, in addition, the properties of the inhibitor prepared from human sperm acrosomes are identical to those of the Fraction II inhibitor (Zaneveld et al., 1972), it appears likely that the Fraction II inhibitor is the one involved in the reproductive process. The high association constant of the Fraction II inhibitor, which in reality may be even somewhat higher than that calculated for 5 min of incubation since complete inhibition 
was not obtained until a few minutes later (Text-fig. 1), explains the rapid complex formation between the acrosomal proteinase and the inhibitor under physiological conditions. Spontaneous dissociation of this complex in the female genital tract during capacitation is, however, somewhat difficult to imagine. Either a factor must be present in the female genital tract secretions to induce the dissociation, or the acrosomal proteinase and inhibitor are not actually in a complex on the spermatozoon, i.e. the enzyme may be located within the acrosome and the inhibitor on the surface of the sperm head. In the second case, a complex would be formed as the enzyme is released from the spermatozoon due to the high affinity of the enzyme for the inhibitor. Residence of the spermatozoon in the female genital tract causes changes in the surface components of the sperm head (Ericsson, 1969; Oliphant \& Brackett, 1972), possibly resulting in the removal of inhibitor from the spermatozoon, thus allowing the enzyme to exert its activity. Some evidence for the localization of the inhibitor on the surface of the acrosome can be surmised from the results of Hirschhauser \& Baudner (1972), which showed that seminal plasma trypsin inhibitor antibodies bind to the sperm head. Both hypotheses explain the fact that natural trypsin inhibitors do not prevent fertilization if added to ejaculated spermatozoa before deposition in the vagina (Schumacher, Swartwout \& Zuspan, 1971), but do interfere with fertility on addition to capacitated spermatozoa before insemination into the oviduct (Zaneveld et al., 1971). In contrast, synthetic proteinase inhibitors such as tosyl-lysine chloromethyl ketone (TLCK, mol. wt. $=363$ ) that most likely pass through the outer acrosomal membrane and form an irreversible complex with the acrosomal proteinase, prevent fertilization on incubation with ejaculated as well as capacitated spermatozoa (Zaneveld, Robertson \& Williams, 1970).

The research upon which this publication is based was performed pursuant to Contract No. NIH 70-2317 and NIH Grant No. 1-RO1-HD-06315 with the National Institutes of Health, Department of Health, Education and Welfare (G.F.B.S. and L.J.D.Z.) and by funds of the Sonderforschungsbereich 51 of the Deutsche Forschungsgemeinschaft (H.F., E.F. and E.J.).

\section{REFERENGES}

ERIcsson, R. J. (1969) Methods for measurement of sperm capacitation in different species. Adv. Biosci. 4, 51.

Fink, E., Jaumann, E., Fritz, H., Ingrisch, H. \& Werle, E. (1971) Protease-Inhibitoren im menschlichen Spermaplasma. Isolierung durch Affinitätschromatographie und Hemmverhalten. Hoppe-Seyler's Z. physiol. Chem. 352, 1591.

Fritz, H., Forg-Brey, B., Fink, E., Schiessler, H., Jaumann, E. \& Arnhold, M. (1972) Charakterisierung einer Trypsin-ahnlichen Proteinase (Akrosin) aus Eberspermien durch ihre Hemmbarkeit mit verschiedenen Protein-Proteinase-Inhibitoren. I. Seminale Trypsin-Inhibitoren und Trypsin-Kallikrein-Inhibitor aus Rinderorganen. Hoppe-Seyler's Z. physiol. Chem. 353, 1007.

Green, N. M. \& Work, E. (1953) Pancreatic trypsin inhibitor II. Reaction with trypsin. Biochem. J. $54,347$.

HirschHauser, G. \& Baudner, S. (1972) Immunologic localization of the human seminal plasma protease inhibitor in human spermatozoa. Fert. Steril. 23, 393.

Laskowski, M. J. \& Sealock, R. W. (1971) Protein proteinase inhibitors-molecular aspects. In: The Enzymes, Vol. III, p. 375. Ed. P. D. Boyer. Academic Press, New York. 
OLIPHANT, G. \& BRACKetT, B. G. (1972) Immunological approach for assaying rabbit sperm capacitation. Biol. Reprod. 7, 102.

Schumacher, G. F. B., Swartwout, J. R. \& Zuspan, F. P. (1971) Fertility experiments in mice and rabbits with the trypsin-kallikrein inhibitor from bovine lung. In: Proc. Int. Res. Conf. on Proteinase Inhibitors, Munich, Germany, 1970, p. 247. Eds. H. Fritz and H. Tschesche. W. DeGruyter, Berlin and New York.

Schwert, G. W. \& Takenake, Y. (1955) A spectrophotometric determination of trypsin and chymotrypsin. Biochim. biophys. Acta, 16, 570 .

Stambaugh, R., Bracketr, B. G. \& Mastroianni, L. (1969) Inhibition of in vitro fertilization of rabbit ova by trypsin inhibitors. Biol. Reprod. 1, 223.

Suominen, J. J. \& Niemi, M. (1972) Human seminal trypsin inhibitors. F. Reprod. Fert. 29. 163.

Zaneveld, L. J. D., Dragoje, B. M. \& Schumacher, G. F. B. (1972) Acrosomal proteinase and proteinase inhibitor of human spermatozoa. Science, N.Y. 177, 702.

Zaneveld, L. J. D., Robertson, R. T., Kessler, M. \& Williams, W. L. (1971) Inhibition of fertilization in vivo by pancreatic and seminal plasma trypsin inhibitors. F. Reprod. Fert. 25, 387.

Zaneveld, L. J. D., Robertson, R. T. \& Williams, W. L. (1970) Synthetic enzyme inhibitors as antifertility agents. FEBS Lett. 11, 345.

Zaneveld, L. J. D., Srivastava, P. N. \& Williams, W. L. (1969) Relationship of a trypsin-like enzyme in rabbit spermatozoa to capacitation. F. Reprod. Fert. $20,337$.

Zaneveld, L. J. D., SRivastava, P. N. \& Williams, W. L. (1970) Inhibition by seminal plasma of acrosomal enzymes in intact sperm. Proc. Soc. exp. Biol. Med. 113, 1172. 